\title{
Etyka bez metafizyki? Moralne implikacje myślenia postmetafizycznego
}

\section{ETHICS WITHOUT METAPHYSICS? MORAL IMPLICATIONS OF POST-METAPHYSICAL THINKING}

The main purpose of this article is to analyze the relationship between post-metaphysical thinking, nihilism and ethics. Nihilism denotes a broadlyconceived cultural phenomenon in which the idea of nothingness plays a crucial role. Different kinds of nihilism may thus be identified with a set of thoughts, beliefs and behaviours dominated by the concept of nothingness. Models of postmetaphysical ethics, developed by two Italian philosophers Gianni Vattimo and Emanuele Severino, are very important manifestations of a contemporary ethical thinking, which - in the face of radical challenges brought by the biotechnological revolution - representatives of very different philosophies, cultures and religions claim to be necessary.

Key words: ethics, bioethics, metaphysics, Habermas, Severino, Vattimo, nihilism, post-metaphysical thinking.

\section{Wprowadzenie}

W 1988 roku niemiecki filozof Jürgen Habermas wprowadził pojęcie „myślenia postmetafizycznego” (nachmetaphysisches Denken) do języka współczesnej humanistyki i ogólnoświatowej domeny publicznej

$1 \quad$ Por. J.Habermas, Nachmetaphysisches Denken. Philosophische Aufsätze, Berlin 1988. 
Dwadzieścia cztery lata później ukazało się kolejne ważne i inspirujące dzieło tego autora, w którym rozwija on swoją koncepcję myślenia postmetafizycznego i odpowiada na różnego rodzaju krytykę, wątpliwości i zarzuty, jakie pojawiły się w ostatnich latach pod adresem jego inspirującej propozycji filozoficznej².

Czy można tworzyć modele etyczne bez metafizyki? Jakie są implikacje etyczne myślenia postmetafizycznego? Czy ma rację Habermas, gdy twierdzi, że zmiany, jakie dokonały się w filozofii po Fryderyku Wilhelmie Heglu są nieodwracalne? Jak oceniać współczesne modele etyki postmetafizycznej i rolę semantycznego potencjału religii? Głównym celem artykułu jest ukazanie istoty myślenia postmetafizycznego w wydaniu Habermasa oraz analiza dwóch modeli etyki postmetafizycznej, wypracowanych w sporze z nihilizmem przez dwóch włoskich filozofów - Gianniego Vattima i Emanuela Severina.

\section{Metafizyka po Heglu}

Habermas jest przekonany o tym, że nie mamy dzisiaj żadnej alternatywy dla myślenia postmetafizycznego. Jak należy rozumieć tę koncepcję niemieckiego filozofa? Zdaniem Habermasa, myślenie postmetafizyczne jest przede wszystkim odpowiedzią na kryzys metafizyki po Heglu oraz próbą uwzględnienia zmian, jakie dokonały się w świecie nauki na przestrzeni ostatnich dwóch stuleci. Habermas twierdzi, że po Heglu został podważony ,przywilej poznawczy filozofii" (das Erkenntnisprivileg der Philosophie), jej podstawowe pojęcia zostały zdetranscendentalizowane oraz zostało zakwestionowane pierwszeństwo teorii przed praktyką. W konsekwencji tych głębokich zmian teoria filozoficzna utraciła swój szczególny status, jaki posiadała przez tysiąclecia w wielu kulturach i cywilizacjach.

Szczególnie interesujące są uwagi Habermasa na temat relacji myślenia postmetafizycznego do religii. Jego zdaniem, filozofia w swej postaci postmetafizycznej nie może ani zastąpić religii, ani jej usunąć z przestrzeni życia publicznego. Co więcej, filozofia postmetafizyczna przejawia zupełnie nowe zainteresowanie fenomenem religijnym w kontekście liberalnych i postsekularnych społeczeństw cywilizacji zachodniej3.

$2 \quad$ Por. idem, Nachmetaphysisches Denken II: Aufsätze und Repliken, Berlin 2012.

3 Por. J. Habermas, Die Grenze zwischen Glauben und Wissen, „Revue de métaphysique et de morale" 44 (2004) 44, s. 460-484; idem, Zwischen Naturalismus und Religion. Philosophische Aufsätze, Berlin 2005; idem, Verbalizzare il sacro. Sul lascito religioso della filosofia, Roma - Bari 2015. 
Habermas jest przekonany o religijnym dziedzictwie filozofii. Twierdzi, że religia i filozofia mają wspólną genealogię. Werbalizując sacrum, tzn. dokonując przetłumaczenia świata sakralnego na język współczesnej świeckiej cywilizacji człowieka zachodniego, doprowadzamy do faktycznego wchłonięcia religii przez filozofię ${ }^{4}$. Religia zostaje przezwyciężona przez filozofię, poniekąd rozpuszcza się w przestrzeni filozoficznej, ale jednocześnie nie przestaje trwać jej wewnętrzna treść i przesłanie intelektualne. Przezwyciężony duch religii zachowuje swoje treści w filozofii ${ }^{5}$.

Wydaje się, że możemy zastosować do opisu tego procesu niemiecką kategorię „Aufhebung”, której Hegel używał do ukazania wzajemnych interakcji w dziejowej spirali tez i antytez, tworzącej swego rodzaju matrycę $\mathrm{w}$ dialektycznym rozwoju procesu historycznego - jak teza zostaje przezwyciężona przez antytezę, z zachowaniem swej istotnej wewnętrznej treści, tak też dzisiaj - według Habermasa - religia zostaje „zniesiona” i wchłonięta przez filozofię, zachowując jednak swoją wewnętrzną treść, czyli tzw. potencjał semantyczny.

\section{Myślenie postmetafizyczne i etyka nihilistyczna}

Myślenie postmetafizyczne spotyka się dzisiaj z fenomenem nihilizmu. W czym tkwi jego istota? Nihilizm oznacza szeroko rozumiane zjawisko intelektualne, moralne i kulturowe, w którym idea nicości odgrywa szczególną rolę. Można je utożsamić z pewnym zespołem myśli, przekonań i zachowań, zdominowanych przez pojęcie nicości. Do najbardziej widocznych jego przejawów zaliczamy rozpad trwałego fundamentu moralności i kultury, przewartościowanie wartości, doświadczenie pustki czy absurdalności istnienia ${ }^{6}$. Nihilizm stał się przedmiotem namysłu filozoficznego w kontekście idealizmu niemieckiego, a ważnym etapem w jego dziejach był ruch rewolucyjny w Rosji Ethics w XIX wieku. Największym prorokiem i teoretykiem nihilizmu jest niewątpliwie Fryderyk Nietzsche - trafnie nazywający siebie pierwszym doskonałym nihilistą Europy.

4 Por. W. Huber, Mit Gottund allen Agnostikern. Ausgenüchtert, nichtfarbenblind: Jürgen Habermas will den Dialog von Glauben und Religionskritik, „Die Zeit” (2012) 51, s. 54.

$5 \quad$ Por. V. Possenti, Fede e ragione, dialogo con Habermas, „Avvenire” 48 (2015) 77, s. 21.

$6 \quad$ Por. A. Zaccuri, Il nichilismo travolto dal fato, „Avvenire” 47 (2014) 305, s. 21. 
Jedną z najciekawszych współczesnych diagnoz nihilizmu wypracował włoski filozof Gianni Vattimo ${ }^{7}$. Oryginalność jego koncepcji polega na twórczej akceptacji nihilizmu, połączonej z propozycją etyki nihilistycznej, która stanowi jedną z form etyki postmetafizycznej. Vattimo prezentuje historię nihilizmu jako osłabienia, „zmiękczenia” twardej wersji bycia i mocnych kategorii metafizycznych.

Tego rodzaju proces prowadzi do zastąpienia nihilizmu tragicznego nihilizmem konstruktywnym - jest to bezpośrednie nawiązanie do postaci nihilisty spełnionego, która pojawia się w pismach Nietzschego. Nihilista spełniony to ten, który zrozumiał, że nihilizm jest jego jedyną szansą, nie rozpacza z powodu końca metafizyki, ale widzi w nim szansę na odnalezienie nowej pozycji człowieka w stosunku do bycia. Tego rodzaju nihilizm wyrasta z przekonania, że porzucenie wartości o charakterze ostatecznym i nadprzyrodzonym stanowi jedyną szansę na prawdziwą wolność człowieka.

Interpretacja nihilizmu łączy się u Vattima z koncepcją myśli słabej (pensiero debole). Myśl słaba stanowi konsekwencję kryzysu powstałego w wyniku stopniowego zaniku racjonalności mocnej, czyli jedynej i uniwersalnej, jaka charakteryzowała minione stulecia. Pensiero debole to metafora, w pewnym stopniu paradoksalna, bardziej prowokacja intelektualna niż dostatecznie jasno sformułowana teoria filozoficzna. W jej świetle historia Zachodu to postępujące osłabienie bycia, które dotychczas w chrześcijaństwie i nowożytnej nauce znajdowało swoje decydujące i fundujące momenty.

Myśl słaba rodzi się na zgliszczach myśli mocnej (pensiero forte), czyli wiedzy typowej dla tradycji metafizycznej Zachodu i sięgającej swymi korzeniami starożytnej Grecji, która dążyła do określenia spójnej, monolitycznej, stabilnej i niezmiennej struktury rzeczywistości tout court. Chodzi tutaj o poznanie - jak twierdzi Vattimo - ufundowane na „błędzie Platona”, który polega na tym, że byciu przypisujemy charakter wieczności i stabilności. W konsekwencji świat naszej konkretnej egzystencji zostaje spustoszony i pozbawiony wartości. Dla myśli mocnej poznanie oznacza przede wszystkim szukanie prawdy jako niezależnego i stabilnego punktu odniesienia, który jest pewny i bezpieczny dla wszystkich ${ }^{8}$.

$7 \quad$ Por. A. Kobyliński, Nihilism and Ethics in the Philosophy of Weak Thought of Gianni Vattimo, „Seminare” 37 (2016) 4, p. 55-67; L. Fazzini, Credenti e no, patto sul nichilismo, „Avvenire” 48 (2015) 78, s. 23; A. Lavazza, Lo spettro di Nietzsche vaga per l'Europa, „Avvenire” 47 (2014) 255, s. 23; S. Natoli, La salvezza è per tutti. E l'apostolo accettò una religione „laica”, „Avvenire” 48 (2015) 105, s. 22.

8 Por. A. Dal Lago, P. A. Rovatti, Elogio del pudore. Per un pensiero debole, Milano 1989, s. 9-22. 
Vattimo twierdzi, że w obliczu współczesnego nihilizmu jest możliwa etyka stricte laicka - pozbawiona fundamentu metafizycznego czy odniesienia do transcendencji. $Z$ jednej strony, tego rodzaju etyka budzi wiele wątpliwości i jest zagrożona relatywizmem, z drugiej - stanowi jeden z ważnych modeli etycznych, które wychodzą naprzeciw różnego rodzaju dylematom moralnym, obecnym we współczesnych społeczeństwach zsekularyzowanych i wielokulturowych.

Apologia nihilizmu, reinterpretacja nihilistyczna orędzia chrześcijańskiego i powstanie jego wersji słabej mają kluczowe znaczenie dla określenia możliwości zbudowania etyki nihilistycznej, która odwołuje się przede wszystkim do współczucia i miłosierdzia. Vattimo twierdzi, że w obliczu rozpadu fundamentu i roztopienia się bycia nie możemy zbudować jakiegokolwiek modelu etyki metafizycznej, będącej aplikacją pierwszych zasad. Jedyną możliwą dzisiaj etyką jest etyka postmetafizyczna, która przyjmuje postać etyki nihilistycznej. Wyrasta ona na gruncie hermeneutyki i jest typową etyką postmetafizyczną, która nie stanowi jakiegokolwiek systemu norm i imperatywów. Etyka nihilistyczna nie ma też żadnego trwałego fundamentu, z którego można by wyprowadzać zasady i zobowiązania o charakterze uniwersalnym.

Vattimo traktuje etykę szeroko jako „filozofię w relacji do społeczeństwa, w sposób szczególny do społeczeństwa współczesnego" ${ }^{\text {. }}$ W tej perspektywie istotą etyki jest tworzenie wspólnotowego charakteru naszych zachowań i kształtowanie więzi międzyludzkich. Vattimo kieruje refleksję etyczną głównie w stronę napięć występujących między naszą przynależnością wspólnotową a zachowaniami indywidualnymi, opierając się zwykle „na argumentacji czysto retorycznej, tzn. na serii argumentów ad hominem, dopasowanych do osób, z którymi mamy do czynienia" 10 .

Zdaniem Vattima, obecnie etyka bardziej niż kiedykolwiek uwzględnia aspekty społeczne naszych zachowań. Przejawem tego procesu są narodziny wielu różnych etyk stosowanych, np. etyki medycznej czy dziennikarskiej. Coraz bardziej kwestie dotyczące eutanazji, klonowania człowieka czy manipulacji genetycznych są dyskutowane zasadniczo w kategoriach społecznej akceptacji dla takich zachowań. Także etyka wielkich religii wydaje się dzisiaj w mniejszym stopniu ukierunkowana na definiowanie „dobra i zła w kategoriach sumienia indywidualnego"11. Współczesna etyka, jako dyskurs skoncentrowany

9 G. Vattimo, Tecnica ed esistenza. Una mappa filosofica del Novecento, Milano 2002, s. 76-77.

$10 \quad$ Idem, La filosofia al presente, Milano 1990, s. 86.

11 Idem, Nichilismo ed emancipazione. Etica, politica e diritto, Milano 2003, s. 70. 
na obowiązkach i wartościach konstytuujących życie, podlega transformacji polegającej na przesunięciu uwagi z pola zachowań na sferę społeczną czy publiczną.

Etyka Vattima jest etyką formalną i niejako dziedziczy wszystkie dylematy, związane z systemem etycznym Kanta. W ramach etyki nihilistycznej nie jest zatem możliwa jakakolwiek forma etyki szczegółowej, która wskazuje oceny i normy odnoszące się do określonych gatunków czynów ludzkich. Pozostaje jedynie ogólny imperatyw, którym jest zasada miłosierdzia oraz praktyczna reguła postępowania, aby czynić to, co ogranicza przemoc i powiększa współczucie.

Miłosierdzie w naturalny sposób współgra z demokratycznym pluralizmem oraz z postulatami społecznej solidarności; jest ich istotnym uzasadnieniem. Bez głębszej podstawy w postaci chrześcijańskiego miłosierdzia trudno sobie wręcz wyobrazić, by rozbudowane systemy solidarności mogły przetrwać. Postawa miłosierdzia jest także receptą na rozwiązanie problemu obecności chrześcijaństwa w przestrzeni publicznej. Tego rodzaju cnota społeczna dotyczy dzisiaj religii tout court. Rezygnacja z twardego dogmatyzmu oraz położenie nacisku na „miękką" cnotę miłosierdzia stanowią jedyną możliwą formę funkcjonowania religii w społeczeństwach pluralistycznych i wielokulturowych. Bez postawy miłosierdzia de facto niemożliwą staje się demokracja i nowożytny model społeczeństwa otwartego.

Etyka proponowana przez Vattima jest bardzo abstrakcyjna i niezdolna do wypracowania norm moralnych o charakterze szczegółowym, ale należy pamiętać, że filozof z Turynu tworzy swoją etykę z myślą o współczesnych społeczeństwach zsekularyzowanych i wielokulturowych. Nihilistyczna etyka współczucia i miłosierdzia, chociaż słaba i ograniczona, trafnie formułuje rozwiązania w dziedzinie więzi międzyludzkich i życia społecznego: nakazuje troskę o słabych, wykluczonych, doświadczonych przez zło i przemoc. Natomiast w pewnym stopniu pozostaje bezradna wobec współczesnych problemów bioetycznych.

Postmetafizyczna etyka nihilistyczna, pozbawiona fundamentu metafizycznego i właściwego pojęcia osoby ludzkiej, zbyt łatwo akceptuje różnego rodzaju negatywne przejawy współczesnej rewolucji biotechnologicznej. Przyjęcie przez Vattima dynamicznej koncepcji natury człowieka oraz wskazanie dialogu, porozumienia czy tradycji kulturowej jako jedynego źródła zasad moralnych, tworzy podatny grunt dla różnego rodzaju manipulacji biotechnologicznych oraz prób zmiany istoty naszego człowieczeństwa. 


\section{Technika jako forma nihilizmu}

Własny model etyki postmetafizycznej wypracował także włoski filozof Emanuele Severino. Poddaje on w swoich pismach ostrej krytyce cywilizację zachodnią zdominowaną przez nihilizm, w której technika i naukowo-technologiczne panowanie człowieka nad światem stały się formą etyki. Jedyne remedium na nihilizm i kryzys wartości moralnych Severino upatruje w powrocie do Parmenidesowskiej wizji rzeczywistości. Severino dostrzega istotę cywilizacji zachodniej w nihilizmie metafizycznym rozumianym jako „przekonanie o nicości bytu” ${ }^{12}$. Oznacza to, że cywilizacja zachodnia nie rozpoznaje nihilizmu w rzeczywistej postaci. Jego istota pozostaje ukryta, jego fundamentalne elementy są wciąż tłumaczone w sposób nihilistyczny. Nihilizm jest „,sensem historii Zachodu, która znajduje swoje korzenie w metafizyce greckiej, rozwijając się w zachodniej nauce i technice" ${ }^{13}$.

Zdaniem Severina, w rzeczywistości wszystko jest wieczne: ludzie, rzeczy, świat, gesty, myśli, uczucia itp. Zaprzeczeniem szaleństwa Zachodu, który utożsamia bycie i nicość jest objawianie się wieczności wszystkich rzeczy. Stawanie się świata nie jest stwarzaniem i unicestwianiem rzeczy, ale ukazywaniem i skrywaniem tego, co wieczne. Jesteśmy wieczni i śmiertelni: to, co wieczne wkracza na scenę i z niej schodzi. W tej perspektywie śmierć jest nieobecnością wieczności.

Dla Severina cywilizacja techniczna stanowi najbardziej radykalną formę nihilizmu, czyli przekonania, że rzeczy świata są nicością. Współczesna technika stała się możliwa dzięki nowożytnej nauce. Nauka zaś ma charakter nihilistyczny, ponieważ utożsamia byt i nicość. Metody naukowe pozwalają dostrzec jedynie konkretne rzeczy, to, co się aktualnie objawia, pomijając horyzont całości istnienia. Severino twierdzi, że nasza epoka historyczna jest epoką techniki ${ }^{14}$. Największe siły tradycji zachodniej - chrześcijaństwo, humanizm, wiedza filozoficzna, oświecenie itp. - rozumieją technikę, kierowaną przez nowożytną naukę jako narzędzie i środek, od których zależy życie człowieka na ziemi. Dla poszczególnych sił i prądów myślowych technika stanowi środek do realizacji własnych celów. Tego rodzaju przeświadczenie o służebnym charakterze techniki jest jednak dzisiaj fałszywe.

Zdaniem Severina, potęga techniki stała się już w rzeczywistości, albo zaczęła się stawać, celem samym w sobie. Technika zawiera

12 Por. E. Severino, Elenchos, [in:] P. Ciaravolo red., Il problema del fondamento e la filosofia italiana del Novecento, Roma 2006, s. 45-53.

13 E. Severino, Essenza del nichilismo, Milano 1982, 1995², s. 259-260.

14 Por. idem, Discussioni intorno al senso della verità, Pisa 2009, s. 95-116. 
w sobie wewnętrzną zdolność do powiększania własnej mocy i władzy, ciągły jej wzrost stał się najwyższym celem o charakterze planetarnym, któremu jest podporządkowany każdy inny cel. Na takim właśnie podporządkowaniu polega panowanie techniki w naszych czasach. Nowożytna nauka, technika i technologia tworzą pewien zespół wiedzy, działań i zachowań, przez które „człowiek uwalnia się od bólu i ograniczeń" 15 .

Jednak istotą ich działania jest tworzenie, transformacja i destrukcja rzeczy. Nauka nowożytna jedynie dała nowe i bardziej skuteczne metody panowania człowieka nad światem. Prekursorem techniki prowadzącej do unicestwienia bytu był Platon, który przeciwstawił theia techne (Boską technikę) anthropine techne (technice ludzkiej). W dziejach cywilizacji zachodniej dokonywało się stopniowe zmniejszanie zakresu techniki Boskiej w tworzeniu rzeczy i przekształcaniu świata oraz zwiększanie techniki ludzkiej.

Severino proponuje powrót do Parmenidesa, tzn. opowiada się za uznaniem, że byt jest i nie może nie być, a niebyt nie jest i nie może być. Tę prawdę, która od dnia jej narodzin leży uśpiona w myśli zachodniej, trzeba ciągle zgłębiać. Powrót do Parmenidesa jest szansą na przezwyciężenie nihilizmu poprzez uznanie bezpośredniości fenomenologicznej i logicznej niesprzeczności bytu. Byt jest konieczny, niezmienny, niepodzielny i wieczny. Powrót do Parmenidesa wskazuje na coś bardzo istotnego, co zostało utracone w historii Zachodu: wieczność bytu. Dla obydwu filozofów byt przeciwstawia się nicości, nie może nie istnieć. Jeśli byt staje się (rodzi się, umiera), tzn. że go nie ma. Byt jest wieczny, czyli nie rodzi się ani nie zanika ${ }^{16}$.

W Severina krytyce współczesnej cywilizacji technologicznej widzimy poważną niespójność. $Z$ jednej strony, słusznie ostrzega on przed ryzykiem dehumanizacji i manipulacji ze strony współczesnej techniki, z drugiej - akceptuje większość negatywnych form obecnej rewolucji biotechnologicznej, np. próby modyfikacji ludzkiego genomu czy wykorzystywanie ludzkich zarodków do pozyskiwania embrionalnych komórek macierzystych.

Do krytycznej oceny współczesnej cywilizacji technologicznej w wydaniu Severina nawiązuje m.in. Mauro Ceruti, włoski filozof nauki z Wolnego Uniwersytetu Języków i Komunikacji w Mediolanie, który jest - wraz filozofem i socjologiem francuskim Adgarem Morinem - jednym z głównych przedstawicieli tzw. myśli złożonej (pensiero

$15 \quad$ Idem, Essenza del nichilismo, op. cit., s. 135.

16 Por. D. Sperduto, L'essere ed il divenire: da Parmenide ed Empedocle ad Emanuele Severino, „Aquinas” 51 (2008) 1-2, s. 209-221. 
complesso). W swojej najnowszej książce z 2015 roku pt. Koniec wszechnauki występuje zdecydowanie przeciw scjentyzmowi, który stał się nową formą współczesnego fundamentalizmu ${ }^{17}$.

Ceruti twierdzi, że już od ponad stulecia nauka zmieniła swój podstawowy paradygmat i nie uważa siebie za samowystarczalną ${ }^{18}$. Sama nauka zakwestionowała mity, które legły u podstaw scjentyzmu. Przykładem mogą być najnowsze odkrycia w ramach genetyki, które pokazują, że de facto nie ma genów inteligencji, agresji czy talentu muzycznego. Świat genów jest rzeczywistością niezwykle złożoną, w którym ogromną rolę ogrywają wzajemne interakcje i różnego rodzaju powiązania.

W konsekwencji w ostatnich dziesięcioleciach porzucono ideę, że na podstawie praw naukowych można antycypować przyszły rozwój systemów złożonych, mogąc go kontrolować i decydować o jego kierunku. „Prawa są reinterpretowane jako ograniczenia, które regulują, a nie determinują, przyszły rozwój systemu złożonego. Definiują wielką przestrzeń możliwości przyszłej ewolucji danego systemu"19. Wielką rolę odgrywają takie czynniki jak historia czy pojedyncze wydarzenia, których nie można antycypować. Dlatego powinniśmy obecnie przejść od determinizmu naukowego do większej świadomości znaczenia tego, co nieokreślone w relacji człowieka do natury.

Ceruti twierdzi, że potrzeba dzisiaj „wychowania do złożoności” (educazione alla complessità) - trzeba odejść od fragmentaryzacji dyscyplin naukowych, aby ułatwić możliwość uchwycenia istoty rzeczywistości w jej złożoności. Uniwersytety i szkoły uczą nas, aby oddzielać od siebie poszczególne dyscypliny wiedzy, ale dzisiaj bardziej niż kiedykolwiek potrzeba wychowania ukierunkowanego na zrozumienie kontekstu, na łączenie tego, co w rzeczywistości tworzy jedną wielką całość.

17 Por. M. Ceruti, La fine dell'onniscienza, Roma 2015.

18 „Soppravvivono - twierdzi Mauro Ceruti - ancora alcuni miti: di poter fare previsioni certe, di saper controllare gli effetti delle nostre interazioni tecnologiche con la natura, di dissolvere con la luce della conoscenza scientifica le questioni metafisiche e di senso dell'interrogazione filosofica. Tutti miti che è proprio la scienza stessa ad aver messo in discussione" (La scienza ha ucciso lo scientismo - Andrea Galli rozmawia z Mauro Cerutim, „Avvenire” 48 (2015) 96, s. 24). 


\section{Podsumowanie}

Wielu współczesnych intelektualistów, niezależnie on wyznawanego światopoglądu, dostrzega w nihilizmie największe wyzwanie naszej epoki historycznej. W sporze z nihilizmem - jak trafnie pokazują Vattimo i Severino - jest możliwe wypracowanie adekwatnych modeli etyki postmetafizycznej. Tego rodzaju koncepcje etyczne promują godność człowieka przede wszystkim na poziomie więzi społecznych czy życia publicznego. Pozostają jednak bezradne w obliczu wyzwań współczesnej rewolucji bioetycznej i nie są w stanie chronić godności człowieka od momentu poczęcia do naturalnej śmierci.

Myślenie postmetafizyczne powinno być wolne od „apateizmu” (apateismo), czyli od apatii ateizmu, która oznacza współczesną banalność, powierzchowność i obojętność w stosunku do Transcendencji czy Bytu Najwyższego ${ }^{20}$. W obliczu wyzwań współczesnej cywilizacji technicznej - mając także świadomość destrukcyjnego wpływu apateizmu - potrzeba myślenia pokornego, o którym mówi m.in. filozof francuski Roger Puivet. Jego zdaniem, trzeba zrezygnować z dumy związanej z naszą tradycją kulturową i rozpocząć od etyki cnót. Pokora jawi się tutaj jako najważniejsza cnota w wymiarze społecznym, szczególnie w dialogu $\mathrm{z}$ innymi kulturami, światopoglądami i systemami etycznymi ${ }^{21}$.

\section{ETYKA BEZ METAFIZYKI? MORALNE IMPLIKACJE MYŚLENIA POSTMETAFIZYCZNEGO}

Głównym celem artykułu jest analiza relacji istniejącej między myśleniem post-metafizycznym, nihilizmem i etyką. Nihilizm oznacza szeroko pojęte zjawisko kulturowe, w którym kategoria nicości odgrywa centralną rolę. Dlatego różne rodzaje nihilizmu można określić jako pewien zespół myśli, przekonań i zachowań, zdominowanych przez pojęcie nicości. Modele etyki postmetafizycznej, opracowane przez dwóch włoskich filozofów Gianniego Vattima i Emanuela Severina, stanowią bardzo ważny przykład współczesnego myślenia etycznego, które - w obliczu radykalnych wyzwań, jakie niesie ze sobą rewolucja biotechnologiczna - jest dzisiaj uznawane przez wielu przedstawicieli różnych filozofii, kultur i religii za koniecznie potrzebne.

Słowa kluczowe: etyka, bioetyka, metafizyka, Habermas, Severino, Vattimo, nihilizm, myślenie postmetafizyczne.

20 Por. Siamo malati di apateismo - Monica Mondo rozmawia z Gianfranco Ravasim, „Avvenire” 48 (2015) 99, s. 23.

$21 \quad$ Por. E. Grimi, È l'ora del pensiero umile, „Avvenire” 47 (2014) 282, s. 25. 


\section{Bibliografia:}

1. Ceruti M., La fine dell'onniscienza, Roma 2015.

2. Dal Lago A., Rovatti P. A., Elogio del pudore. Per un pensiero debole, Milano 1989, s. 9-22.

3. Fazzini L., Credenti e no, patto sul nichilismo, „Avvenire” 48 (2015) 78, s. 23.

4. Grimi E., È l'ora del pensiero umile, „Avvenire” 47 (2014) 282, s. 25.

5. Habermas J., Die Grenze zwischen Glauben und Wissen, „Revue de métaphysique et de morale" 44 (2004) 44, s. 460-484.

6. Habermas J., Nachmetaphysisches Denken II: Aufsätze und Repliken, Berlin 2012.

7. Habermas J., Nachmetaphysisches Denken. Philosophische Aufsätze, Berlin 1988.

8. Habermas J., Verbalizzare il sacro. Sul lascito religioso della filosofia, Roma - Bari 2015.

9. Habermas J., Zwischen Naturalismus und Religion. Philosophische Aufsätze, Berlin 2005.

10. Huber W., Mit Gott und allen Agnostikern. Ausgenüchtert, nicht farbenblind: Jürgen Habermas will den Dialog von Glauben und Religionskritik, „Die Zeit" (2012) 51, s. 54.

11. Kobyliński A., Nihilism and Ethics in the Philosophy of Weak Thought of Gianni Vattimo, „Seminare” 37 (2016) 4, s. 55-67.

12. La scienza ha ucciso lo scientismo - Andrea Galli rozmawia z Mauro Cerutim, „Avvenire” 48 (2015) 96, s. 24.

13. Lavazza A., Lo spettro di Nietzsche vaga per l'Europa, „Avvenire” 47 (2014) 255, s. 23.

14. Natoli S., La salvezza è per tutti. E l'apostolo accettò una religione „laica”, „Avvenire” 48 (2015) 105, s. 22.

15. Possenti V., Fede e ragione, dialogo con Habermas, Avvenire" 48 (2015) 77, s. 21.

16. Severino E., Discussioni intorno al senso della verità, Pisa 2009.

17. Severino E., Essenza del nichilismo, Milano 1982.

18. Severino E., Elenchos, [in:] P. Ciaravolo red., Il problema del fondamento e la filosofia italiana del Novecento, Roma 2006, s. 45-53.

19. Siamo malati di apateismo - Monica Mondo rozmawia z Gianfranco Ravasim, „Avvenire” 48 (2015) 99, s. 23.

20. Sperduto D., L'essere ed il divenire: da Parmenide ed Empedocle ad Emanuele Severino, „Aquinas” 51 (2008) 1-2, s. 209-221.

21. Vattimo G., La filosofia al presente, Milano 1990.

22. Vattimo G., Nichilismo ed emancipazione. Etica, politica e diritto, Milano 2003.

23. Vattimo G., Tecnica ed esistenza. Una mappa filosofica del Novecento, Milano 2002.

24. Zaccuri A., Il nichilismo travolto dal fato, „Avvenire” 47 (2014) 305, s. 21. 